\title{
KOSENTRASI LIMBAH PERTANIAN SEBAGAI PAKAN ALTENATIF TERHADAP MORTALITAS DAN PERTUMBUHAN IKAN NILA (Oreochromis niloticus)
}

\author{
Ismail Failu ${ }^{1}$ Safrin Edy ${ }^{2}$ \\ ${ }^{1)}$ Program Studi Pengelolaan Sumberdaya Perairan, Fakultas Pertanian \\ Universitas Muhammadiyah Buton, Baubau, Indonesia \\ 'Program Studi Agribisnis, Fakultas Pertanian \\ Universitas Muhammadiyah Buton, Baubau, Indonesia \\ e-mail: ismailfailu56@gmail.com
}

\begin{abstract}
The research aims (1). Knowing changes concentration in agricultural waste, especially water spinach kale and spinach as a sourace of food for growth and survival of tilapia (Oreochromis niloticus). (2). Knowing at what concentration of agricultural waste, especially bran kale and spinach as a source of food for growth and survival of tilapia (Oreochromis niloticus). The study was conducted in March to May 2020 in the Village of Liabuku, Bungi sub-district, Baubau town. The experimental design used in this study was a Completely Randomized Design (CRD) with 4 levels of treatment and 3 replications, thus there were 12 experimental units (Gasperstz, 1991), namely: (1) Pellet Feed (Mill) / Control (2) Treatment A (70 kale waste $+20 \%$ snail flour +10 rice bran), (3) Treatment B (60 Kale waste $+30 \%$ snail flour +10 rice bran $))$, (4) Treatment $C$ (50\% kale waste + $40 \%$ snail flour +10 rice bran). The provision of concentrations in the form of agricultural waste, especially kale, snail flour and bran as a source of food does not have a significant effect on absolute growth, survival rates and feed conversion to tilapia (Oreochromis niloticus) that are kept in ponds using nets. Absolute growth, survival rates and the best feed conversion at treatment $C(50 \%$ Kale Waste $+40 \%$ snail flour + rice bran 10) which are maintained in a pond using a net.
\end{abstract}

Keywords: Concentration of Agricultural Waste, Mortality and Growth

\begin{abstract}
Abstrak
Penelitian ini bertujuan (1) Mengetahui perubahan kosentrasi pada limbah pertanian khususnya kangkung dedak dan bayam sebagai sumber pakan terhadap pertumbuhan dan kelangsugan hidup ikan nila (Oreochromis niloticus), (2) Mengetahui pada kosentrasi berapa limbah pertanian khususnya kangkung dedak dan bayam sebagai sumber pakan terhadap pertumbuhan dan kelangsugan hidup ikan nila (Oreochromis niloticus). Penelitian dilaksanakan pada Maret sampai dengan Mei 2020 bertempat di Kelurahan Liabuku, Kecamatan Bungi, Kota Buabau. Rancangan percobaan yang digunakan dalam penelitian ini yaitu Rancangan Acak Lengkap (RAL) dengan 4 taraf perlakuan dan 3 kali ulangan, dengan demikian terdapat 12 unit percobaan (Gasperstz, 1991), yaitu: (1) Pakan Pelet (Pabrik)/Kontrol (2) Perlakuan A (Limbah kangkung 70 + tepung bekicot 20\% + dedak padi 10), (3) Perlakuan B (Limbah Kangkung $60+$ tepung bekicot 30\% + dedak padi 10), (4) Perlakuan C (Limbah Kangkung $50 \%$ + tepung bekicot $40 \%$ + dedak padi 10). Pemberian kosentrasi berupa limbah pertanian khususnya kangkung, tepung bekicot dan dedak sebagai sumber pakan tidak memberikan pengaruh yang nyata terhadap pertumbhan mutlak, tingkat kelangsungan hidup dan konversi pakan terhadap ikan nila (Oreochromis niloticus) yang dipelihara di kolam tanah menggunakan waring. Pertumbuhan
\end{abstract}


mutlak, tingkat kelangsungan hidup dan konversi pakan terbaik pada perlakuan C (Limbah Kangkung 50\% + tepung bekicot $40 \%$ + dedak padi 10) yang dipelihara di kolam tanah menggunakan waring.

Kata Kunci: Kosentrasi Limbah Pertanian, Mortalitas Dan Pertumbuhan.

\section{PENDAHULUAN}

Ikan nila (Oreochromis niloticus) merupakan salah satu jenis komoditas akuakultur yang mempunyai nilai ekonomis tinggi sebagai ikan konsumsi air tawar di dunia (FAO 2014). Saat ini ikan nila penyebarannya sangat luas bahkan ke Negara-negara di lima benua yang beriklim tropis dan subtropis. Wilayah yang beriklim dingin, ikan nila tidak dapat hidup baik (Suyanto, 2003). Ikan nila sangat populer di kalangan masyarakat, selain harganya murah, ikan ini mempunyai cita rasa yang lezat dan kandungan protein yang tinggi, tekstur daging ikan nila sangat disukai kalangan masyarakat.

Ikan nila salah satu jenis ikan air tawar yang termasuk dalam program yang dicanangkan oleh pemerintah untuk menggiatkan kembali perikanan budidaya sehingga perlu dilakukan pengembangan teknologi budidaya yang berkaitan dengan ketersediaan induk dan benih yang berkualitas. Namun masih ada beberapa kendala yang sampai saat ini belum terpenuhi yaitu masih rendahnya kualitas benih, tidak tersedianya benih setiap saat secara berkesinambungan, rendahnya fertilisasi telur dan derajat tetas telur. Salah satu penyebab penurunan kualitas telur dan larva diduga karena rendahnya kualitas pakan induk yang diberikan. Pada umumnya pakan induk yang digunakan dalam proses pembenihan ikan nila adalah pakan komersil untuk pembesaran dan bukan pakan yang dibuat khusus untuk tujuan pembenihan, sehingga hasil yang diperoleh tidak optimal baik ditinjau dari segi kualitas maupun kuantitas benih (Darwisito $d k k$., 2008).

Pakan merupakan komponen utama yang menjadi tolak ukur untuk keberlangsungan usaha budidaya. Ketersediaan bahan baku pakan sangat dibutuhkan untuk menunjang usaha budidaya tersebut. Oleh karena itu, perlu adanya alternatif yang kandungan nutrisinya tinggi, berkualitas, mudah ditemukan dan memilikiki nilai ekonomis yang dapat di jangkau oleh pembudiya ikan. Bahan pakan alternatif yang dapat digunakan yaitu limbah pertanian khususnya kangkung dedak dan bayam sebagai sumber pakan. Bahan utama pakan alternatif sumber protein asal tumbuhan yaitu limbah sayur ketersediaannya cukup melimpah dan belum dimanfaatkan untuk penunjang budidaya ikan. Hal ini dikarenakan limbah sayuran sangat mudah busuk tetapi di dalamnya masih mengandung zat - zat makanan yang dimanfaatkan oleh ikan.

Penelitian tentang ketentuan tertinggi pemakaian limbah sayuran belum dilakukan secara maksimal, dengan adanya pengolahan dan penelitian terlebih dahulu, hingga limbah sayuran bebas dari bahan beracun untuk digunakan sebab limbah sayuran tersebut sudah tidak mengandung bakteri pembusuk (Sudjana, 2006). Sejauh ini pemanfaatan kangkung dan bayam lebih banyak diterapkan pada hewan ternak seperti kelinci. Oleh karena itu, penelitian mengenai limbah pertanian perlu dilakukan untuk meningkatkan persentase tertinggi pada limbah pertanian sebagai bahan alternatif yang dapat memberikan laju pertumbuhan dan kelangsungan hidup ikan khususnya budidaya ikan nila.

\section{METODE PENELITIAN}


Penelitian dilaksanakan pada Maret sampai dengan Mei 2020 bertempat di Kelurahan Liabuku, Kecamatan Bungi, Kota Buabau. Alat ukur timbanngan analitik, Alat ukur kualitas air (thermometer, DO meter, $\mathrm{pH}$ meter)

\section{Wadah dan Media Penelitian}

Wadah atau tempat pengamatan adalah waring ukuran 100 kali 100 kali 100 senti meter diletakkan dalam kolam air tawar. Jumlah wadah sebanyak dua belas petak. Organisme uji yang diamti adalah bibit ikan nila yang berukuran 7 - 9 senti meter dengan tebaran persatuan unit kolam tanah (waring) yakni 10 ekor. Makanan percobaan yang diberikan selama pengamatan adalah pelet, kangkung, dedak dan bayam $10 \%$ dari berat badan dan ditebar sesuai perlakuan.

\section{A. Rancangan Percobaan}

Cara kerja yang dilaksanakan semssa pengamatan adalah cara teratur yang digunakan untuk melaksanakan suatu eksperimen agar tercapai sesuai denga yang dikehendaki, serta program yang dilakukan dalam pengamatan adalah Rancangan Acak Lengkap (RAL) dengan empat taraf perlakuan dan tiga kali pengulangan, dengan demikian terdapat 12 unit percobaan.

Setiap perlakuan organisme uji ditebar 10 ekor perunit kolam dengan berat rata-rata 16 gram pada setiap wadah kolam tanah (waring). Perlakuan yang digunakan adalah :

* Pakan Pelet (Pabrik)/Kontrol

- Perlakuan A (Limah kangkung 70 + tepung bekicot 20\% + dedak padi 10)

* Perlakuan B (Limah Kangkung $60+$ tepung bekicot $30 \%$ + dedak padi 10)

* Perlakuan C (Limah Kangkung 50\% + tepung bekicot 40\% + dedak padi 10)

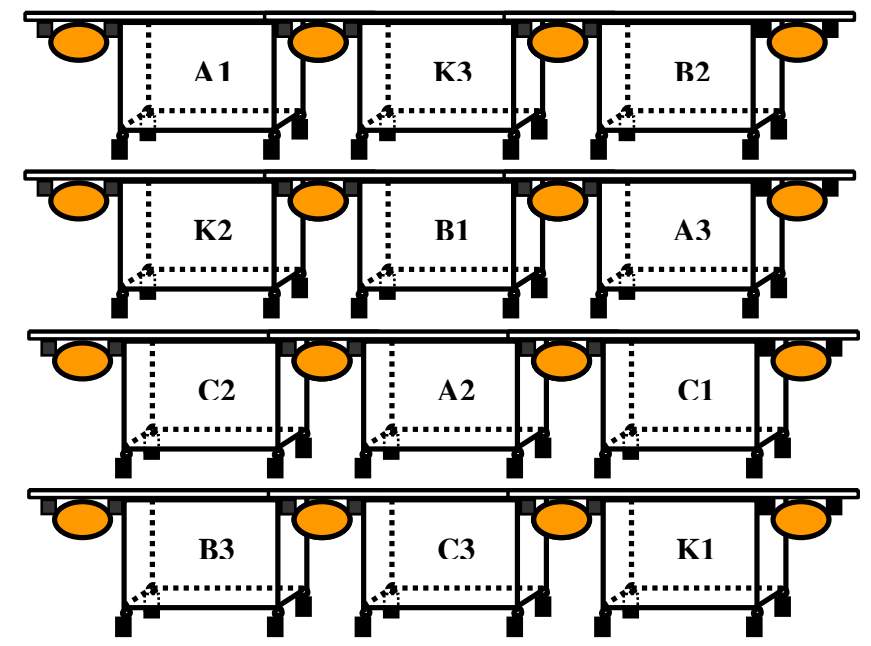

Gambar 5. Layout Wadah Penelitian.

\section{B. Pelaksanaan Penelitian}

\section{Persiapan Pakan}

1. Siapkan pakan komersil dan limbah kangkung, tepung bekicot dan bayam

2. Kangkung dan bayam diuci dengan air kemudian potong-potong sesuai ukuran bukaan mulut ikan.

3. Campurkan kangkung, tepung bekicot dan bayam sesuai perlakuan.

\section{Pemberian Pakan}

Pakan yang digunakan adalah pakan komersil, kangkung, tepung bekicot dan dedak padi. Cara memberikan makanan dilaksanakan tiga kali sehari yakni pada pagi, siang dan sore hari dengan banyaknya memberikan makanan $10 \%$ dari berat ikan perhari. 


\section{Aklimatisasi (Adaptasi Lingkungan) Ikan Nila}

Ketika akan dilaksanakan penelitian maka terlebih dahulu melakukan aklimatisasi (adaptasi) ikan terhadap lingkungan dan pakan. Tahapan yang perlu jalankan untuk aklimatisasi ikan yaitu :

1. Persediaan perlengkapan organisme uji (ikan nila), memakai kolam tanah yang telah disiapkan untuk wadah aklimatisasi (adaptasi lingkungan).

2. Organisme uji (ikan nila) dimasukkan ke dalam kolam tanah yang sudah ditempatkan sesuai dengan jumlah ikan yang dapat ditebar persatuan luas kolam air yang telah direncanakan yaitu 10 ekor benih ikan nila tiap kolam tanah.

3. Adaptasi lingkungan organisme dilakukakan selama 1 minggu untuk mengamati apakah ikan nila dapat mencocokan diri terhadap kolam tanah yang telah disediakan sesuai lingkungan sebelumnya.

4. Penyesuain pakan terhadap organisme uji.

\section{Pengukuran Peubah}

\section{Pertumbuhan Mutlak}

Untuk mengukur pertumbuhan ikan nila dilakukan dengan alat ukur timbangan dengan ketelitian 0,001 gram. Pertumbuhan mutlak dihitung sesuai metode Effendi, (1979) sebagai berikut $: \mathbf{h}=\mathbf{W t}-\mathbf{W 0}$ Keterangan $: \mathrm{h}=$ Pertumbuhan bobot mutlak (gram), Wt $=$ Ratarata bobot individu pada akhir penelitian (gram), W0 = Rata-rata bobot individu pada awal penelitian (gram)

\section{Tingkat Ketahanan Hidup}

Tingkat ketahanan hidup organisme uji dijumlahkan dengan memakai patokan Effendi (1979) sebagai berikut: $\mathbf{T K H}=\frac{\mathbf{N t}}{\mathbf{N} \mathbf{0}} \mathbf{x} \mathbf{1 0 0 \%}$ Diketahui : TKH $=$ Jumlah ketahanan hidup (\%), $\mathrm{N}_{\mathrm{t}} \quad=$ banyaknya organisme uji yang hidup akhir penelitian, $\mathrm{N} 0=$ Jumlah organisme uji yang hidup awal penelitian

3. Konversi Pakan KP $=\frac{\mathbf{F}}{(\mathbf{W t}+\mathbf{D})-\mathbf{W} \mathbf{0}}$ Keterangan : $\mathrm{KP}=$ Konversi Pakan, $\mathrm{F}=$ jumlah pakan yang diberikan, $\mathrm{W} 0=$ Bobot badan awal penelitian, $\mathrm{Wt}=$ Bobot badan akhir penelitian, $\mathrm{D}=$ Jumlah bobot ikan yang mati selama penelitian

\section{Pengukuran Mutu Air}

Sebagai proses sarana dalam pengamatan, maka diamati beberapa proses parameter mutu air pada media uji yang mencakup : temperature (Suhu), Derajat Keasaman $(\mathrm{pH})$, salinitas, Oksigen dan amoniak.

\section{Analisa Data}

Untuk data yang digunakan adalah bentuk deskriptif dan statistika, yaitu mengenai pertumbuhan, tingkat kelangsungan hidup dan konversi pakan. Analisis data dilakukan secara statistik dengan mengunakan uji ANOVA (Analysys of Variance) dengan tingkat kepercayaan 95\% dan jika berpengaruh nyata maka dilanjutkan dengan Uji Tukey untuk mengetahui hasil perlakuan pakan dengan penambahan limbah pertanian kangkung, tepung bekicot, dan dedak padi yang terbaik terhadap pertumbuhan mutlak, tingkat kelangsungan hidup dan konversi pakan (Kusriningrum, 2008), dengan menggunakan Program Statistical Product and Service Solution (SPSS) versi 17.0. 


\section{Hasil}

\section{Pertumbuhan Mutlak}

Hasil penelitian yang telah dilakukan, diperoleh data rata-rata pertumbuhan bobot mutlak melalui perlakuan limbah pertanian sebagai pakan altenatif terhadap pertumbuhan mutlak ikan nila (Oreochromis niloticus) dapat dilihat pada Tabel 2.

Tabel 2. Rata-rata pertumbuhan bobot mutlak ikan nila (Oreochromis niloticus) Selama Penelitian

\begin{tabular}{ccccc}
\hline \multirow{2}{*}{ Ulangan } & \multicolumn{4}{c}{ Perlakuan } \\
\cline { 2 - 5 } & $\mathbf{K}$ & $\mathbf{A}$ & $\mathbf{B}$ & $\mathbf{C}$ \\
\hline $\mathbf{1}$ & 11,52 & 10,81 & 11,42 & 15,23 \\
$\mathbf{2}$ & 9,92 & 6,32 & 14,62 & 19,78 \\
$\mathbf{3}$ & 14,70 & 14,77 & 15,03 & 19,91 \\
\hline Total & $\mathbf{3 6 , 1 4}$ & $\mathbf{3 1 , 9 0}$ & $\mathbf{4 1 , 0 8}$ & $\mathbf{5 4 , 9 2}$ \\
\hline Rata-rata & $\mathbf{1 2 , 0 5}{ }^{\text {ns }}$ & $\mathbf{1 0 , 6 3}^{\text {ns }}$ & $\mathbf{1 3 , 6 9}^{\text {ns }}$ & $\mathbf{1 8 , 3 1}^{\text {ns }}$ \\
\hline *ns = non signifikan pada taraf $\boldsymbol{\alpha} \mathbf{0 , 0 5}$ & &
\end{tabular}

Dari hasil penelitian terlihat bahwa perlakuan limbah pertanian sebagai pakan altenatif terhadap pertumbuhan ikan nila (Oreochromis niloticus) memberikan pertumbuhan yang bebeda. Dimana pertumbuhan mutlak tertinggi terdapat pada perlakuan Perlakuan C (Limah Kangkung 50\% + tepung bekicot $40 \%$ + dedak padi 10) sebesar 18,31 gram, selanjutnya Perlakuan B (Limah Kangkung 60 + tepung bekicot 30\% + dedak padi 10) sebesar 13,69 gram, Pakan Pelet (Pabrik)/Kontrol sebesar 12,05 gram dan yang terendah pada Perlakuan A (Limah kangkung $70+$ tepung bekicot $20 \%$ + dedak padi 10) sebesar 10,63 gram.

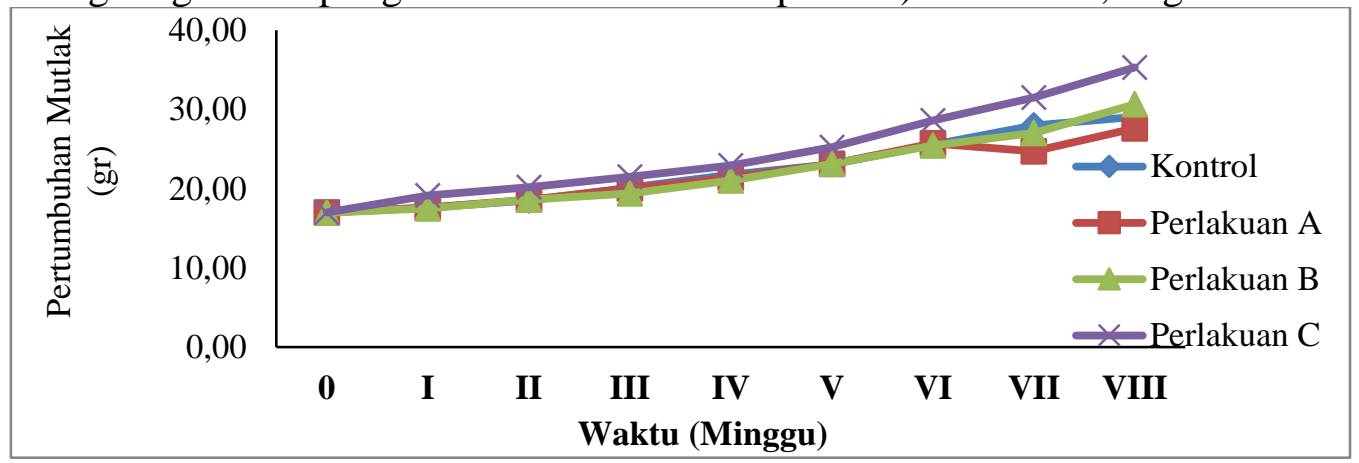

Grafik 6. Pertumbuhan Mutlak Ikan Nila (Oreochromis niloticus)

Berdasarkan gambar 6 di atas perlakuan mengalami peningkatan pertumbuhan mutlak setiap perlakuan dari minggu I sampai dengan minggu VIII, terkecuali pada perlakuan Perlakuan A (Limah kangkung 70 + tepung bekicot $20 \%$ + dedak padi 10) mengalami penurunan pada minggu ke VII.

Berdasarkan hasil analisis sidik ragam perlakuan limbah pertanian sebagai pakan altenatif terhadap pertumbuhan mutlak ikan nila (Oreochromis niloticus) tidak berpengaruh nyata terhadap pertumbuhan mutlak ikan nila.

\section{Tingkat Kelangsungan Hidup}

Hasil penelitian yang sudah dilakukan, diperoleh data rata-rata tingat kelangsungan hidup ikan nila melalui perlakuan limbah pertanian sebagai pakan altenatif pada tingkat ketahanan hidup ikan nila (Oreochromis niloticus) dapat dilihat pada Tabel 3.

Tabel 3. Tingkat Ketahanan Hidup ikan nila (Oreochromis niloticus) semassa pengamatan 


\begin{tabular}{ccccc}
\hline \multirow{2}{*}{ Ulangan } & \multicolumn{4}{c}{ Perlakuan } \\
\cline { 2 - 5 } & K & A & B & C \\
\hline $\mathbf{1}$ & 90 & 90 & 90 & 90 \\
$\mathbf{2}$ & 90 & 80 & 100 & 100 \\
$\mathbf{3}$ & 100 & 100 & 100 & 100 \\
\hline Total & $\mathbf{2 8 0}$ & $\mathbf{2 7 0}$ & $\mathbf{2 9 0}$ & $\mathbf{2 9 0}$ \\
\hline Rata-rata & $\mathbf{9 3}^{\text {ns }}$ & $\mathbf{9 0}^{\text {ns }}$ & $\mathbf{9 6 , 6 7}$ ns & $\mathbf{9 6 , 6 7}$ ns \\
\hline
\end{tabular}

*ns = non signifikan pada taraf $\alpha 0,05$

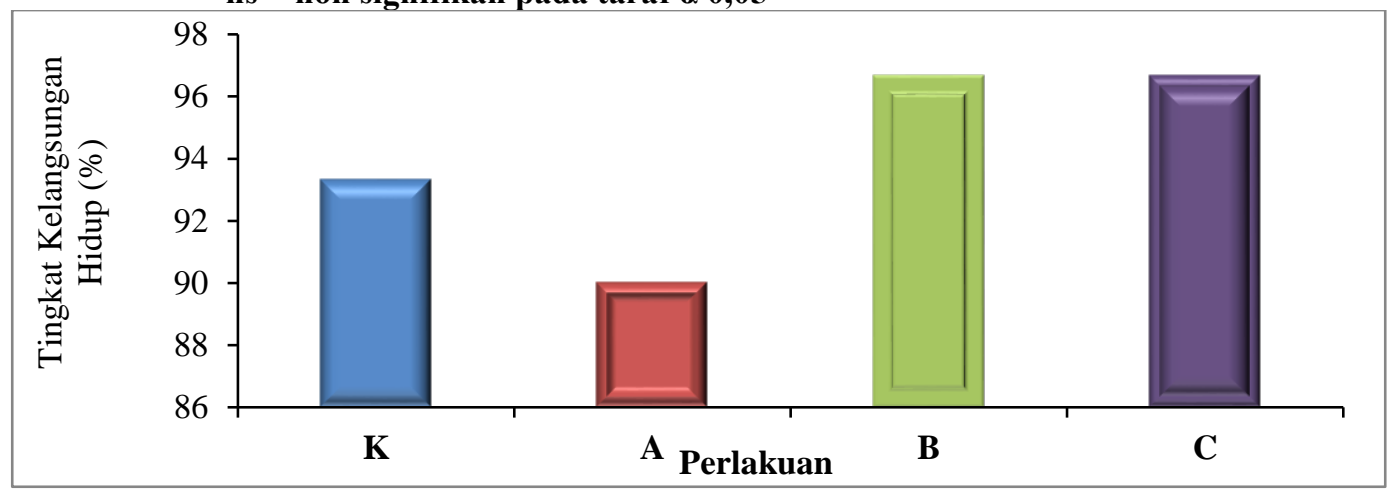

Gambar 7. Diagram Kelangsungan Hidup ikan nila (Oreochromis niloticus).

Berdasarkan tabel 3 dan gambar 7 diatas tingkat kelangsungan hidup ikan nila (Oreochromis niloticus) selama 60 hari pemeliharaan terlihat yang tertinggi terdapat pada perlakuan B (Limah Kangkung 60 + tepung bekicot $30 \%$ + dedak padi 10) yaitu sebesar 96,67\%, kemudian perlakuan C (Limah Kangkung 50\% + tepung bekicot 40\% + dedak padi 10) sebesar 96,67\%, selanjutnya pada perlakuan Pakan Pelet (Pabrik)/Kontrol sebesar 93\% dan yang terendah pada perlakuan A (Limah kangkung $70+$ tepung bekicot $20 \%+$ dedak padi 10) sebesar $90 \%$.

Berdasarkan hasil analisis sidik ragam perlakuan limbah pertanian sebagai pakan altenatif terhadap tingkat kelangsungan hidup ikan nila (Oreochromis niloticus) tidak berpengaruh nyata.

\section{Konversi Pakan}

Konversi pakan merupakan nilai berbeda dari banyaknya makanan yang diperlihatkan semassa penelitian untuk perkembangan dan tingkat kelangsungan hidup ikan sampai dapat diketahui baik maupun buruknya mutu makanan yang diberikan. Nilai rata-rata konversi pakan ikan nila (Oreochromis niloticus) dapat disajikan pada Tabel 3.

Tabel 3. Konversi Pakan ikan nila (Oreochromis niloticus) selama Penelitian.

\begin{tabular}{ccccc}
\hline \multirow{2}{*}{ Ulangan } & \multicolumn{4}{c}{ Perlakuan } \\
\cline { 2 - 5 } & $\mathbf{K}$ & $\mathbf{A}$ & $\mathbf{B}$ & $\mathbf{C}$ \\
\hline $\mathbf{1}$ & 12,80 & 17,69 & 17,50 & 12,62 \\
$\mathbf{2}$ & 15,17 & 24,45 & 15,84 & 12,12 \\
$\mathbf{3}$ & 15,50 & 15,52 & 14,95 & 12,54 \\
\hline Total & $\mathbf{4 3 , 4 7}$ & $\mathbf{5 7 , 6 6}$ & $\mathbf{4 8 , 2 8}$ & $\mathbf{3 7 , 2 9}$ \\
\hline Rata-rata & $\mathbf{1 4 , 4 9}$ & $\mathbf{1 9 , 2 2}$ & $\mathbf{1 6 , 0 9}$ & $\mathbf{1 2 , 4 3}$ \\
\hline *ns = non signifikan pada taraf $\boldsymbol{\alpha} \mathbf{0 , 0 5}$ & &
\end{tabular}




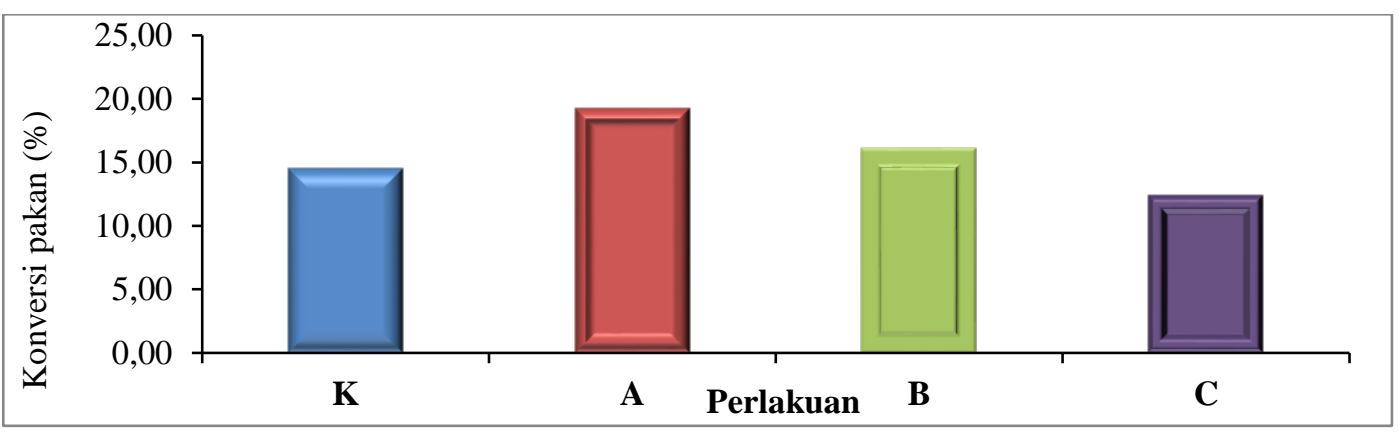

Gambar 8. Diagram Konversi Pakan ikan nila (Oreochromis niloticus).

Berdasarkan tabel 4 dan gambar 8 diatas konversi pakan ikan nila (Oreochromis niloticus) selama 60 hari pemeliharaan terlihat yang tertinggi terdapat pada perlakuan $\mathrm{C}$ (Limah Kangkung 50\% + tepung bekicot 40\% + dedak padi 10) sebesar 12,43\%, kemudian Pakan Pelet (Pabrik)/Kontrol sebesar 14,49\%, selanjutnya pada perlakuan B (Limah Kangkung 60 + tepung bekicot $30 \%$ + dedak padi 10) 16,09\%, dan yang terendah pada perlakuan A (Limah kangkung 70 + tepung bekicot 20\% + dedak padi 10) sebesar 19,22\%

Berdasarkan hasil analisis sidik ragam perlakuan pemanfaatan limbah pertanian sebagai pakan altenatif terhadap konversi pakan tidak berpengaruh nyata.

\section{Mutu Air}

Mutu air ikan nila selama 8 minggu waktu pemeliharaan dilihat pada Tabel 4 . Tabel 4. Kisaran kualitas air selama penelitian

\begin{tabular}{cccc}
\hline Parameter & Perlakuan & Nilai & Kisaran Optimal \\
\hline \multirow{5}{*}{ Suhu $\left(\mathrm{C}^{\circ}\right)$} & $\mathrm{K}$ & $24-26$ & \\
& $\mathrm{~A}$ & $25-27$ & $24\left(\mathrm{C}^{\circ}\right)-27\left(\mathrm{C}^{\circ}\right)$ \\
& $\mathrm{B}$ & $25-27$ & $($ Nasution, 2000) \\
\hline & $\mathrm{C}$ & $25-27$ & $6-8$ \\
$\mathrm{pH}$ & $\mathrm{K}$ & $7.16-7.40$ & (Nasution, 2000) \\
& $\mathrm{A}$ & $7.16-7.40$ & $6,5-8,0$ \\
& $\mathrm{~B}$ & $7.16-7.34$ & Kordi dan Tanjung (2007) \\
\hline & $\mathrm{C}$ & $7.18-7.40$ & (Tappin, 2010) \\
DO & $\mathrm{K}$ & $5.19-5.50$ & \\
& $\mathrm{~A}$ & $5.29-5.50$ & 0,1 - 0,3 mg/L \\
& $\mathrm{B}$ & $5.30-5.44$ & $($ Boyd, 1991) \\
Amoniak & $\mathrm{C}$ & $5.18-5.40$ & \\
$(\mathrm{mg} / \mathrm{L})$ & $\mathrm{K}$ & $0,018-0,039$ & \\
& $\mathrm{~A}$ & $0,017-0,034$ &
\end{tabular}

\section{E. Pembahasan}

\section{Pertumbuhan Mutlak}

Pertumbuhan menjadikan peralihan ukuran panjang atau berat dalam peroide tertentu. Pertumbuhan bobot mutlak dinyatakan sebagai perubahan ukuran bobot dalam kurun waktu tertentu, sedangkan laju pertumbuhan harian dinyatakan sebagai persentase pertumbuhan bobot per hari (Effendie, 2002). 
Pada penelitian ini pertumbuhan bobot mutlak yang diukur berupa berat rata-rata pertambahan ukuran biomassa perunit percobaan selama penelitian. Pertumbuhan bobot mutlak terbaik adalah pada perlakuan C (Limah Kangkung 50\% + tepung bekicot $40 \%+$ dedak padi 10) sebesar 16,31 gram, selanjutnya B (Limah Kangkung $60+$ tepung bekicot $30 \%$ + dedak padi 10) sebesar 13,69 gram dan diikuti perlakuan kontrol (Pakan Komersil) sebesar 12,05 gram dan yang terendah pada perlakuan A (Limah kangkung $70+$ tepung bekicot $20 \%$ + dedak padi 10) sebesar 10,63 gram.

Berdasarkan hasil analisis sidik ragam (ANOVA) menunjukan bahwa perlakuan limbah pertanian sebagai pakan altenatif tidak berpengaruh terhadap pertumbuhan ikan nila (Oreochromis niloticus). Berdasarkan hasil analisis proksimat tepung bekicot perbedaan protein pakan pada setiap perlakuan sangat kecil yakni perlakuan A protein pakan 17,27, perlakuan, perlakuan B protein pakan 21,44 dan C protein pakan 21,26. Riri Ezraneti et al 2018 menjelaskan bahwa perkembangan ikan dapat terdiri atas banyaknya protein pada makanan dan mengatasi yang dibutuhkan bagi pemeliharaan tubuhnya.

Protein sangat bermanfaat bagi tubuh untuk pertumbuhan dan perkembangan perbaikan tubuh, dan pergantian sel-sel susunan tubuh serta pembuatan produksi enzim penghancuran dan penyerapan makanan didalam perut dan enzim pertukaran zat pada organisme yang meliputi proses fisika dan kimia, pembentukan dan penguraian zat di dalam badan yang memungkinkan berlangsungnya hidup.

Perbedaan pertumbuhan bobot mutlak pada setiap perlakuan disebabkan adanya perbedaan nutrisi pakan yang diberikan pada ikan nila. Adrian (2012), susunan komposisi kimia daun dan batang pada kangkung air segar mempunyai ketentuan air $(85,64 \%$ dan $85,04 \%)$, ketentuan abu $(0,54 \%$ dan $0,56 \%)$, ketentuan lemak $(0,21 \%$ dan $0,19 \%)$, ketentuan protein $(3,10 \%$ dan $3,23 \%)$, dan ketentuan serat kasar $(1,16 \%$ dan $1,17 \%)$. Selama proses pembuatan penyulingan hanya ketentuan protein yang menjalani peningkatan susunan kimia menjadi (4,04\% dan 4,13\%). Mineral makro yang terdapat pada daun dan batang kangkung air segar mengandung Kalsium 42,00 mg/100 g dan 47,00 mg/100 g; Fosfor 29,00 mg/100 g dan 31,00 mg/100 g, Magnesium 10,373 mg/100 g dan 21,956 mg/100 g, Kalium 247,00 $\mathrm{mg} / 100 \mathrm{~g}$ dan $217,00 \mathrm{mg} / 100 \mathrm{~g}$ dan Natrium $56,00 \mathrm{mg} / 100 \mathrm{~g}$ dan 48,00 mg/100 g.

Hasil pengamatan memperlihatkan tepung bekicot mampu mewakili tepung ikan sampai $50 \%$ dan menjadikan hasil perkembangan pertumbuhan yang baik. Protein amat bermanfaat bagi tubuh yakni untuk pertumbuhan serta perkembangan tubuh, perbaikan dan pergantian sel-sel jaringan tubuh serta produksi enzim pencernaan dan enzim metabolisme. Menurut (Kompiang, 1979) menyatakan bahwa bekicot mengandung protein yang tinggi, yaitu 59,27 gram per 100 gram bahan kering, sehingga ketika dijadikan pakan akan meningkatkan kadar protein ikan tersebut dan pertumbuhan menjadi lebih baik bila dibandingkan dengan ikan yang hanya diberi pakan komersil. Adelina dan Ida (2007) menyatakan bahwa bekicot memiliki kadar protein yang sangat tinggi sehingga dapat menghasilkan laju pertumbuhan yang optimal. Penggunaan tepung bekicot dengan komposisi $75 \%$ dan tepung ikan $25 \%$ mendapatkan hasil pertumbuhan ikan yang sangat tinggi, sehingga penggunaan tepung bekicot dapat dimanfaatkan untuk menggantikan tepung ikan. Komposisi tepung bekicot menurut Kompiang (1979) adalah air 7,54 g, protein 57,72 g, lemak 4,60 g, kalsium 7,83 g, fosfor 0,95 g, dan serat kasar 0,08 g. Menurut (Garsetiasih $d k k, 2003$ ), menyatakan bahwa Dedak padi memiliki kandungan gizi yakni adalah bahan kering $86,5 \%$, abu $8,7 \%$, protein kasar 10,8\%, serat kasar 11,5\%, lemak 5,1\%, bahan ekstrak tanpa nitrogen (BETN) 50,4\%, kalsium $0,2 \%$ dan phosfor $2,5 \%$. 


\section{Tingkat Kelangsungan Hidup}

Kelangsungan hidup (Survival Rate) yaitu angka persen jumlah ikan nila yang masih hidup setelah perlakuan (Zonneveld $d k k$., 1991). Kelangsungan hidup berfungsi untuk menghitung persentase ikan yang hidup pada akhir penelitian. Hasil penelitian ini menunjukan bahwa pemanfaatan limbah pertanian sebagai pakan altenatif terhadap tingkat kelangsungan hidup ikan nila (Oreochromis niloticus) tidak berpengaruh nyata terhadap kelangsungan hidup ikan nila $(\mathrm{P}<0,05)$.

Pada Perlakuan A (Limah kangkung 70 + tepung bekicot $20 \%$ + dedak padi 10) terlihat pada gambar 7 diatas bahwa terjadi mortalitas atau kematian ikan nila paling tinggi dengan nilai kisaran yaitu 90\%. Hal ini disebabkan Handling (penanganan) yang kurang teliti pada saat penimbangan yang menyebabkan ikan melompat keluar wadah penelitian. Teknik handling yang tidak tepat selanjutnya adalah pada saat penangkapan menyebabkan sisik ikan terlepas yang pada tahap selanjutnya menyebabkan luka dan stres. Penurunan tingkat kelangsungan hidup selanjutnya yaitu polah tingkah laku ikan yang sering menggosok gosokkan badannya pada wadah waring penelitian. Djunaidah (2004), menjelakskan bahwa kelulushidupan dapat mempengaruhi keadaan biotik dan abiotik. Keadaan biotik terdiri dari umur dan kemampuan ikan dalam menyesuaikan diri terhadap lingkungan. Faktor abiotik antara lain ketersediaan makanan dan kualitas sarana media hidup ikan. Kesiapan makanan dalam penelitian ini dapat diduga cukup untuk memenuhi kebutuhan ikan dalam mempertahankan diri untuk dan pertumbuhan kelangsungan hidup.

\section{Konversi Pakan}

Feed Conversion Ratio adalah suatu ukuran yang menyatakan rasio jumlah pakan yang dibutuhkan untuk menghasilkan $1 \mathrm{~kg}$ daging ikan kultur. Besar kecilnyan rasio konversi pakan dipengaruhi oleh beberapa faktor tetapi yang paling terpenting adalah kualitas dan kuantitas pakan, spesies, ukuran dan kualitas air.

Pada penelitan yang dilakukan selama 8 minggu memperlihatkan nilai konversi pakan perlakuan C (Limah Kangkung 50\% + tepung bekicot 40\% + dedak padi 10) memiliki nilai tertinggi yaitu sebesar 12,43\%, kemudian perlakuan Pakan Pelet (Pabrik)/Kontrol yaitu sebesar 14,49\%, diikuti oleh perlakuan B (Limah Kangkung $60+$ tepung bekicot $30 \%+$ dedak padi 10) yaitu sebesar $16,09 \%$, dan yang terndah pada perlakuan A (Limah kangkung 70 + tepung bekicot $20 \%$ + dedak padi 10) yaitu sebesar 19,22\%. Berdasarkan hasil analisis sidik ragam pengaplikasian limbah pertanian sebagai pakan altenatif tidak berpengaruh pada semua perlakuan. Hal ini diduga akibat rendahnya kemampuan ikan nila untuk mencerna Limbah kangkung, tepung bekicot, dedak padi. Menurut Widodo (2014) kecernaan merupakan suatu penilaian berdasarkan bagian dari energi yang tidak dapat dibagi lagi dari pemanfaatan makanan maupun bagian dari keseluruhan nutrisi. Tingkat kecernaan atau menghancurkan makanan hingga menjadi cair dan dapat menyerap kedalam darah terhadap suatu jenis makanan bergantung pada mutu makanan, komposisi bahan pakan, kandungan gizi pakan, jenis serta aktivitas enzim-enzim pencernaan pada sistem pencernaan ikan, ukuran dan umur ikan serta sifat fisik dan kimia perairan. Hal ini sesuai dengan pendapat (Effendi, 1997) menjelaskan ikan dapat menggunakan makanan yang diberikan secara terbaik sehingga pakan tersebut terisap dan diubah menjadi daging.

Pada bidang perikanan daun kangkung air selama ini digunakan sebagai bahan pakan ikan, serta dapat digunakan sebagai alternatif bahan pakan diantaranya sebagai suplemen bahan pakan pada ikan wader (Rasbora argyrotaenia). Daun kangkung merupakan sumber hijauan yang disenangi oleh ikan nila, tetapi penggunaan daun kangkung ini kurang optimal karena masih dianggap gulma bagi beberapa pembudidaya dan daun kangkung air hanya 
berupa limbah. Bentuk limbah ini dikarenakan daun kangkung air memiliki nilai kandungan nutrisi serat kasar yang tinggi. Ramuan dalam pembuatan pakan ikan, kadar serat kasar tidak baik jika bernilai tinggi.

Berdasarkan hasil pengamatan yang dilaksanakan pada setiap perlakuan yakni $12,43 \%$ $19,22 \%$. Nilai ketepatan pada penelitian ini termasuk rendah jika dibandungkan dengan ikan air tawar lainnya seperti pada ikan gabus memiliki nilai sebesar 7.00\%-9,11\% (Deny et al, 2013). Hal ini sesuai pendapat Haryadi et al (2005) menjelaskan keadaan faktor yang menentukan mutu ketepatan makanan adalah yang mempunyai ciri dari sumber nutrisi dan banyaknya dari tiap-tiap komponen yang bersumber dari nutrisi dalam makanan tersebut.

Menurut (Kompiang 1979), mengemukakan bahwa Bekicot mengandung protein $59,28 \%$, lemak $3,62 \%$, serat kasar $2,47 \%$, kalsium $6,4 \%$ dan fosfor $0,85 \%$. Selain itu, kesiapan suatu sarana berkelanjutan, tidak susah ditemukan, serta tidak membawa kandung racun yang dapat mengakibatkan kesehatan dan kemampuan untuk menghasilkan sesuatu benih ikan (Kompiang 1979). Yulisman et al. (2012) berpendapat bahwa ketentuan kadar protein yang tinggi pada pakan akan menghasilkan pertumbuhan dan ketepatan pakan yang kian bertambah tinggi, sebaliknya ketentuan kadar protein yang kurang baik dapat menyebabkan pertumbuhan dan ketepatan pakan yang kurang baik pula.

\section{Mutu Air}

Mutu air sewaktu penelitian berlangsung diamati setiap hari, variable yang dilihat yakni: temperature air atau suhu $\left({ }^{\circ} \mathrm{C}\right)$, oksigen terlarut dan $\mathrm{pH}$ (derajat Keasaman), serta kadar racun dalam air atau amoniak $\left(\mathrm{NH}_{3}\right)$ (dilakukan pengukuran pada awal dan akhir penelitian.

\section{a. Suhu $\left({ }^{\circ} \mathrm{C}\right)$}

Suhu adalah merupakan salah satu parameter utama bagi kehidupan organisme, karena lingkungan akan mempengaruhi aktivitas sel dalam tubuh. Hasil pengukuran suhu yang diperoleh selama penelitian berkisar antara $25-27^{\circ} \mathrm{C}$ (tabel 5 ), Semakin tinggi suhu maka laju metabolisme semakin tinggi, sehingga masih dapat ditoleransi oleh ikan nila, hal ini bahwa suhu yang baik untuk perkembangan pertumbuhan ikan nila yakni $24{ }^{\circ} \mathrm{C}-27{ }^{\circ} \mathrm{C}$, (Nasution 2000)

Hasil pengukuran ini menunjukan bahwa suhu air selama pengamatan masih sesuai yang dibutuhkan ikan nila yakni $25^{\circ} \mathrm{C}-30^{\circ} \mathrm{C}$. Peningkatan suhu selama pemeliharaan disebabkan adanya terkena pengaruh dari tempat dan kegiatan dalam kolam tanah sebab dalam kolam tanah berada di tempat terbuka. Ikan tersebut kedap tidak diam saja untuk mencari tempat berteduh. Ikan juga berusaha giat berpindah mencari makanan dalam wadah budidaya kolam tanah yang diberi waring.

b. $\mathbf{p H}$

Nilai pH semassa penelitian memberikan nila berkisar antara 7,16-7,40 (Tabel 5). Semassa pemeliharaan ada keinginan turunnya nilai $\mathrm{pH}$. Penurunan nilai $\mathrm{pH}$ dapat disebabkan oleh proses tingginya $\mathrm{CO}_{2}$ akibat pengikatan oksigen oleh butir-butir darah untuk penyediaan bahan bagi seluruh tubuh melalui permukaan alat pernapasan sekaligus mengeluarkan karbon dioksida. Nilai pH semassa pengamatan masih pada batas ukur untuk penambahan atau pengurangan yg masih diperbolehkan ikan nila. Nasution (2000) mengemukakan nilai $\mathrm{pH}$ yang baik untuk ikan nila adalah 6-8.

Kesuburan mutu suatu perairan begitu juga ditentukan oleh $\mathrm{pH}$, dimana suatu perairan yang netral lebih menguntungkan jika dibandingkan dengan suatu perairan asam (Hicking, 1971). Power of Hidrogen (pH) merupakan logaritma negatif dari kosentrasi partikel (atom atau molekul) yg bermuatan listrik, yg dihasilkan atau terbentuk dengan penghilangan atau 
penambahan elektron gas tidak berwarna, tidak berbau, tidak ada rasanya, menyesakkan dengan rumus $\mathrm{H} 2$, tetapi tidak bersifat racun, unsur dengan nomor atom 1, berlambang $\mathrm{H}$, dan bobot atom $1,0080\left(\mathrm{pH}=\log \left[\mathrm{H}^{+}\right]\right.$. Air yang belum mendapat pengaruh dari luar pada suhu 25 ${ }^{\circ} \mathrm{C}$ memiliki $\mathrm{pH} 7$, titik mati asam pada $\mathrm{pH} 4$, sedangkan titik mati basa pada $\mathrm{pH} 11$ (Boyd, 1988).

Pengaruh $\mathrm{pH}$ pada umumnya mengakibatkan stres pada ikan atau gangguan yang disebabkan oleh faktor dari luar. Kekuatan air menghentikan pertukaran $\mathrm{pH}$ yang lebih besar kemungkinan penting dari pada nilai $\mathrm{pH}$ itu sendiri dalam kaitannya dengan adanya karbonat, bikarbonat, dan hidroksida. Air dengan kesadahan rendah mempunyai kekuatan yang rendah dalam menahan kegiatan peningkatan nilai keasaman (Boyd, 1988). Pada $\mathrm{pH} 8$ karbondioksida bebas dan asam karbonat sudah tidak ditemukan lagi tetapi terdapat ion partikel atom atau molekul yang bermuatan listrik, yang dihasilkan atau terbentuk dengan penghilangan atau penambahan elektron bikarbonat (Effendi, 2000).

\section{c. Oksigen Terlarut}

Kandungan $\mathrm{O}_{2}$ dalam wadah budidaya ikan nila semassa pengamatan memberikan nilai kisaran antara 5,18-5,50 ppm (Tabel 5). Kandungan $\mathrm{O}_{2}$ memberi tenaga di dalam proses penggabungan suatu zat dengan oksigen yang dibuang serta proses makanan untuk mengeluarkan energi bagi kehidupan dan pertumbuhan juvenil ikan nila. Kandungan $\mathrm{O}_{2}$ yang didapatkan sampai akhir pengamatan masih berada pada kisaran nilai yang baik untuk kehidupan dan perkembangan pertumbuhan benih ikan nila pada tingkat kelangsungan hidup yang masih diatas $70 \%$.

Ikan membutuhkan $\mathrm{O}_{2}$ untuk mengisap dan mengeluarkan napas serta proses penghancuran dan penyerapan makanan di dalam perut yang menghasilkan energi untuk berenang, perkembangan, reproduksi, dan lain-lain (Sucipto dan Prihartono (2007). Kadar oksigen terlarut dalam air dipengaruhi oleh temeratur, kadar garam, dan tekanan atmosfer, selagi berkurangnya kadar $\mathrm{O}_{2}$ dipengaruhi oleh tingginya temperatur dan berkurangnya keadaan atmosfer (Jeffries dan Mills, 1996, dalam Effendi, 2000).

Oksigen terlarut adalah menjadi faktor utama untuk memastikan mutu air untuk budidaya. Ikan nila dapat tumbuh berkembang dalam air dengan kisaran oksigen $3->5$ $\mathrm{mg} /$ liter. Sucipto dan Prihartono (2007), menyatakan menaikkan produktivitas ikan, kisaran $\mathrm{O}_{2}$ dalam air sebaiknya dijaga pada tingkatan diatas $5 \mathrm{mg} /$ liter, jika kisaran $\mathrm{O}_{2}$ selagi berada dibawah $3 \mathrm{mg} / \mathrm{liter}$ dapat menyebabkan penurunan laju pertumbuhan ikan.

\section{d. Amoniak (NH3)}

Pada tabel 5 Amoniak $\left(\mathrm{NH}_{3}\right)$ media pemeliharaan berkisar antara 0,014-0,039 (mg/L). Sucipto dan Prihartono (2007), mennyatakan bahwa amonia merupakan hasil akhir dari proses protein terhadap sisa makanan dan hasil pertukaran zat pada organisme yang meliputi proses fisika dan kimia, pembentukan dan penguraian zat di dalam badan yang memungkinkan berlangsungnya hidup serta yang mengendap didasar perairan, dan merupakan toksik (racun) bagi ikan.

Amonia merupakan bentuk gambaran nitrogen anorganik yang bersifat toksik terhadap organisme budidaya. Boyd (1991), menjelaskan bahwa konsentrasi $\mathrm{NH}_{3}$ pada partikel atom atau molekul yang bermuatan listrik, yang dihasilkan atau terbentuk dengan penghilangan atau penambahan elektro pada air kolam yakni berkisar antara $0,1-0,3 \mathrm{mg} / \mathrm{L}$ berpengaruh mematikan dan konsentrasi ammonia baru bersifat toksik berkisar 0,6 - 2,0 mg/L. Bertambahnya kadar amoniak $\left(\mathrm{NH}_{3}\right)$ menyebabkan banyaknya jumlah sisa makanan dan hasil pertukaran zat pada organisme yang meliputi proses fisika dan kimia, pembentukan dan penguraian zat di dalam badan yang memungkinkan berlangsungnya hidup ikan yang 
mengendap di dasar kolam tanah pemeliharaan yang diberi waring, sementara proses pencucian waring tidak dicuci setiap minggu, sehingga limbah pakan akan menjadi racun dalam air.

Menurut Kordi dan Tanjung (2007), menyatakan bahwa kandungan kadar amoniak (NH3) yang diperoleh dalam suatu perairan seluruhnya merupakan hasil pertukaran zat pada organisme yang meliputi proses fisika dan kimia, pembentukan dan penguraian zat di dalam badan yang memungkinkan berlangsungnya hidup ikan serta berupa kotoran padat (feces) dan terlarut (amonia), yang dikeluarkan lewat anus, ginjal dan jaringan insang. Sisa pencernaan dan pertukaran zat pada organisme yang meliputi proses fisika dan kimia, pembentukan dan penguraian zat di dalam badan yang memungkinkan berlangsungnya hidup ikan yang dikeluarkan dari tubuh dan sisa makanan yang tidak termakan adalah bahan organik dengan kandungan protein tinggi yang diuraikan menciptakan polypeptida, asam-asam amino dan akhirnya amonia sebagai hasil akhir dalam kolam. Makin tinggi kakuatan oksigen, pH dan temperatur air makin tingi pula konsentrasi $\mathrm{NH}_{3}$. Asmawi (1983), menyatakan bahwa gas tidak berwarna, baunya menusuk, terdiri atas unsur nitrogen dan hidrogen, mudah sekali larut dalam air dan jumlah elemen oksigen yang ada dalam larutan yang baik untuk kelangsungan hidup ikan kurang dari 1 ppm.

\section{KESIMPULAN}

Kesimpulan menunjukkan bahwa: (1) Pemberian pengaplikasian limbah pertanian sebagai pakan altenatif tidak memberikan pengaruh nyata terhadap pertumbuhan bobot mutlak, tingkat kelangsungan hidup dan konversi pakan. (2). Angak pertumbuhan bobot mutlak, rasio konversi pakan dan tingkat kelangsungan hidup yang terbaik pada perlakuan $\mathrm{C}$ (Limah Kangkung $50 \%$ + tepung bekicot $40 \%$ + dedak padi 10). Nilai rata-rata untuk pertumbuhan mutlak adalah 18,31 gram, tingkat kelangsungan hidup memberikan nilai rata-rata sebesar 96,67\%. dan konversi pakan dengan nilai rata-rata adalah sebesar 12,43\%.

\section{DAFTAR PUSTAKA}

Adelina dan Ida, S. B. 2007. Pemanfaatan tepung bekicot (Achatina fulica) sebagai bahan pakan benih ikan baung dan ikan mas. Berkala Perikanan.Vol. 1, No. 2: 158-162.

Andrian, 2012. Deskripsi Mikroskopis dan Kandungan Mineral Tanaman Kangkung Air (Ipomoea aquatica Forsk.). http://repository.ipb.ac.id. [Diakses pada tanggal 5 Maret 2020]

Darwisito, S., M. Zairin., D. S. Sjafei., W. Manalu , dan A. O. Sudrajat., 2008. Pemberian Pakan Mengandung Vitamin E dan Minyak Ikan Pada Induk Memperbaiki Kualitas Telur dan Larva Ikan Nila (Oreochromis niloticus). Jurnal Aquacultur Indonesia Vol 7(1): Hal 1-10.

Denny, H; Ida, H. S dan Yulisman. 2013. Kelangsungan hidup, pertumbuhan dan efisiensi pakan ikan gabus (Channa striata) yang diberi pakan berbahan baku keong mas (Pomacea sp.). Jurnal Akuakultur Indonesia. Vol 1., No 2 : 161-172.

Effendie, M.I. 2002. Biologi Perikanan. Yogyakarta: Yayasan Pustaka Nusantara.

[FAO] Food and Agriculture Organization of the United Nations. 2014. The State of World Fisheries and Aquaculture: Opportunities and Challenges. Rome: FAO. 223 pp.

Kompiang, L. P. 1979. Pendayagunaan Bekicot. Kongres Nasional Biologi IV. Bandung. 
Riri Ezraneti, Erlangga dan Erliza Marzuki. 2018. Probiotics fortification in feed to increase the growth of gourami (Osphronemus goramy). Program Studi Ilmu Kelautan, Universitas Malikussaleh, Aceh Utara, Indonesia. Acta Aquatica: Aquatic Sciences Journal, 5:2 (October, 2018): 64-68

Sucipto dan Prihartono (2007), Pembesaran Nila Hitam Bangkok di Karamba Jaring Apung, Kolam Air Deras, Kolam Air Tenang dan Karamba. Penerbit Penebar Swadaya, Jakarta.

Sudjana, A. 2006. Pertumbuhan, Kelangsungan Hidup dan Produksi Ikan Nila Merah (Oreochromis sp) yang dipelihara dalam kurungan terapung pada Berbagai padat Penebaran. Institut Pertanian Bogor. Bandung.

Widodo, Agustono., A. S. dan W. Paramitha., 2014. Kandungan Protein Kasar dan Serat Kasar Pada Daun Kangkung Air (Ipomoea aquatica) Yang Difermentasi. Jurnal Ilmiah Perikanan dan Kelautan Vol 2 (1). Universitas Airlangga

Yulisman, Fitrani, M dan Jubaedah, D. 2012. Peningkatan pertumbuhan danefisiensi pakan ikan gabus (Channa striata) melalui optimasi kandungan dalam pakan. Jurnal Lahan Suboptimal. Vol. 40, No.2: 47-55.

Zonneveld, N; Huisman, E. A; and Boon, J. H. 1991. Prinsip-prinsip Budidaya sIkan. PT Gramedia Pustaka Umum. Jakarta. 